\title{
HUBUNGAN GREEN PERCIEVED VALUE, GREEN BRAND IMAGE, DAN GREEN TRUST TERHADAP GREEN PURCHASE INTENTION
}

\author{
Dewi Rakhmawati 1, Astrid Puspaningrum 2, Djumilah Hadiwidjojo \\ Master in Management Faculty of Economics and Business, \\ Universitas Brawijaya ${ }^{1}$ \\ Fakultas Ekonomi dan Bisnis, Universitas Brawijaya Malang ${ }^{2}$ \\ Email: dewirakhma@gmail.com
}

\begin{abstract}
The issue of environmental damage caused by industry continues to increase every year accompanied bu real conditions that accur, either damage on humans, animals, plants, and the environment. Nowadays people are increasingly aware of the importance of preserving the environment more selectively in the selection of products used. This study was conducted to determine the effect of green perceived value and green brand image on green purchase intention on consumers of Malang Bodyshop. The number of samples study were 141 respondents of The Bodyshop customers in Malang. This study uses a purposive sampling technique with the following criteria: (1) At least 18 years old (2) Domiciled in the city of Malang and once made a purchase at the outlets of The Bodyshop Malang (3) Have used The Bodyshop products at least more than once. Data analysis techniques are performed using Partial Least Square (PLS). The result of the study show that it turns outs that trust in the green products plays a very important role towards the desire of consumers to buy. The result obtained by green trust fully mediate green perceived value and green brand image of the green purchase intention. There is a positive relationship between green perceived value on green trust and green brand image of green trust. It was also found in this study that there was a negative relationship between green perceived value on green purchase intention and the negative relationship between the green brand image of the green purchase intention.
\end{abstract}

Keywords: Green Percieved Value, Green Brand Image, Green Trust, Green Purchase Intention, Green Marketing

\section{Cara mencitasi:}

Rakhmawati, D., Puspaningrum, A., Hadiwidjojo, D. (2019). Hubungan Green Percieved Value, Green Brand Image, Dan Green Trust Terhadap Green Purchase Intention. Iqtishoduna: Jurnal Ekonomi Dan Bisnis Islam. Vol 15 (1): 1-16.

\section{Pendahuluan}

Kondisi lingkungan semakin berubah ke arah yang memprihatinkan seperti kenaikan suhu bumi, pencemaran air, udara, dan tanah yang 
berdampak buruk pada bidang pertanian dan punahnya satwa. Bahkan sampah yang makin hari makin besar jumlahnya dan sulit untuk didaur ulang (Wibowo, 2001). Kondisi lingkungan yang semakin tidak bersahabat membuat masyarakat kian sadar akan pentingnya kepedulian terhadap lingkungan dan mempunyai tanggung jawab besar dalam upaya pelestarian lingkungan. Masyarakat semakin memperhatikan masalah lingkungan dengan alasan bahwa bencana pencemaran lingkungan muncul dari kegiatan industry manufaktur dunia (Chen, 2012). Masyarakat didorong untuk terus berkembang meningkatkan kualitas kehidupannya seiring didukung dengan perkembangan lingkungan pemasaran yang cukup pesat (Shaputra, 2013).

Peningkatan kualitas hidup mendorong tumbuhnya pengetahuan dan kesadaran masyarakat akan lingkungan dalam banyak aspek, yang pada akhirnya menentukan produk yang dipilih dan digunakan, serta bagaimana akibat dari pola konsumsi tersebut melalui gerakan green consumerism yang merupakan lanjutan gerakan konsumen dimana makin menguatnya kesadaran akan hak mereka untuk mendapatkan produk yang layak, aman, serta ramah lingkungan (Grant dalam Shaputra, 2013). Perubahan konsumen ke arah green consumerism menuntut sector industry untuk mengembangkan model produksi dan pemasaran baru yang lebih ramah lingkungan melalui penerapan green marketing dimana tidak hanya menawarkan sebuah produk yang ramah lingkungan, tetapi dimulai sejak proses produksi, proses distribusi, kegiatan pemasaran, sampai kegiatan diluar aktivitas pemasaran juga harus berbasis pada kelestarian lingkungan.

Green marketing tidak hanya menawarkan keuntungan bagi lingkungan, tetapi bagi pelaku dan konsumen. Telah banyak pelaku industry yang menerapkan konsep ini, salah satunya pada industry kosmetik. Hanya saja tantangan perusahaan kosmetik yang berbasis lingkungan adalah kemampuan dalam mengedukasi masyarakat bahwa produk yang mereka gunakan, tidak hanya baik untuk digunakan, tetapi juga baik untuk alam. Terlebih lagi karena penjualan produk kosmetik ramah lingkungan masi relative rendah dibandingkan produk kosmetik biasa. Ardianti (2008) menyatakan bahwa factor usia, tingkat pendidikan, tingkat pendapatan, dan eco-literacy dari konsumen berpengaruh secara nyata terhadap tingkat kesediaan membayar ketika produk tersebut memiliki tanggung jawab terhadap lingkungan.

Setiap pengusaha berbasis lingkungan harus dapat meningkatkan niat membeli konsumen melalui sebuah model green marketing yang mempertimbangkan keutuhan suatu produk bagi pelanggan, nilai produk yang dirasakan konsumen, serta resiko yang dihadapi pelanggan (Chen, 2010). Walaupun green marketing tidak menjanjikan keuntungan besar untuk 
perusahaan, namun dapat meningkatkan aspek social konsumen terutama terhadap alam. Perusahaan harus dapat meningkatkan keinginan membeli konsumen terhadap produk hijau.

Niat membeli konsumen terhadap produk ramah lingkungan akan muncul setelah konsumen melakukan evaluasi, di mana citra hijau sebuah produk memiliki peran dalam membentuk nilai yang akan dievaluasi. Green brand image juga mempengaruhi reputasi perusahaan secara signifikan, di mana citra yang positif menjadi langkah awal menuju kesuksesan menarik konsumen dan menciptakan pelanggan setia (Mourad, 2012). Selain green brand image, green perceived value juga membangun kredibilitas suatu perusahaan berbasis kepedulian lingkungan. Konsumen selayaknya mendapatkan manfaat yang diterima atas penggunaan produk tersebut dengan harapan adanya keberlanjutan lingkungan (Chen dan Chang, 2012). Kredibilitas menjadi salah satu kunci strategi dalam green marketing (Chen dan Chang, 2012). Kredibilitas erat kaitannya dengan trust. Trust yang dihubungkan dengan produk ramah lingkungan adalah kehendak untuk bergantung pada sebuah produk, jasa, atas dasar keyakinan atau harapan yang dihasilkan dari kredibilitas, kebaikan, dan kecakapan tentang kinerja lingkungan (Chen, 2009).

Ketika konsumen percaya terhadap bahwa produk yang akan digunakan adalah benar produk hijau dan berbasis lingkungan, maka akan berpengaruh terhadap sikap yang akan diambil konsumen terhadap produk tersebut, yaitu melakukan pembelian atau tidak. Kemudian pada beberapa penelitian juga menyebutkan bahwa green perceived value dan green brand image mempengaruhi green purchase intention (Chen dan Chang, 2012; Sweene, et al., 1999; Ashton et al. 2010)

\section{Kajian Pustaka \\ Perilaku Konsumen}

Menurut Kotler dan Keller (2008:214) perilaku konsumen dipahami sebagai studi mengenai bagaimana individu, kelompok, dan organisasi memilih, membeli, menggunakan, dan menempatkan barang, jasa, ide, atau pengalaman untuk memuaskan kebutuhan dan keinginan mereka. Beberapa factor yang mempengaruhi perilaku konsumen adalah: factor kebudayaan yang berpengaruh luas dan mendalam terhadap perilaku konsumen, meliputi aspek budaya, subkultur, kelas social, dan lain-lain; Factor social yang terdiri dari kelompok pertemenan, keluarga, serta status social; Factor pribadi yang mempengaruhi perilaku (usia, tahapan sikus hidup, pekerjaan, gaya hidup,

IQTISHODUNA Vol. 15 No. 1 Tahun 2019| 3

http://ejournal.uin-malang.ac.id/index.php/ekonomi 
kepribadian, dan konsep diri; Factor psikologis (motivasi, persepsi, pengalaman, pembelajaran, keyakinan)

\section{Green Marketing}

Green marketing menurut Dahlstrom (2011) menekankan penawaran produk yang tidak berbahaya bagi lingkungan dengan proses pemasaran yang dirancang untuk meminimalkan dampak negative pada lingkungan fisik yang meliputi kegiatan produksi, distribusi, dan reklamasi produk sebagai suatu upaya terpadu dalam upaya pemasaran. Menurut Chen dan Chang (2012) terdapat lima alas an bagi perusahan untuk menggunakan konsep green marketing, yaitu : memanfaatkan peluar pasar hijau, dapat meningkatkan citra perusahaan, dapat meningkatkan nilai produk yang dihasilkan, dapat meningkatkan keunggulan kompetitif perusahaan, dan sesuai dg tren dlingkungan yang ada.

\section{Green Customer Percieved Value}

Patterson dan Spreng (1997) mengatakan bahwa green perceived value adalah penilaian keseluruhan konsumen akan keuntungan bersih dari suatu produk atau layanan antara apa yang diterima dengan apa yang diberikan berdasarkan keinginan konsumen, dengan harapan akan keberlanjutan lingkungan, dan kebutuhan akan green product. Green perceived value tidak hanya dapat menjadi penentu penting dalam mempertahankan hubungan pelanggan jangka panjang, naming juga memegang peran kunci dalam mempengaruhi niat beli (Zeithaml, 1988; Zhuang, et al. 2010).

\section{Green Brand Image}

Green brand image didefinisikan oleh Chen (2010) sebagai keseluruhan rangkaian tayangan, konsepsi dan kekhawatiran terhadap merek dalam memori pelanggan yang terkait dengan masalah keberlanjutan dan ramah lingkungan. Keuntungan utama menciptakan citra merek yang hebat adalah peningkatan kesadaran lingkungan yang pasti, dimana perusahaan dapat memanfaatkan keunggulan kompetitif produk mereka di pasar yang berbeda. Bahkan Ko et al. (2013) juga menyampaikan bahwa hasil pemasaran sebuah green product secara signifikan terkait dengan penciptaan merek yang positif dan hasilnya juga menunjukkan terdapat niat pelanggan untuk menggunakan produk tersebut.

\section{Green Trust}

Kepercayaan tidak didapat begitu saja oleh pihak lain, namun harus dibangun dan dapat dibuktikan. Green trust adalah kesediaan menggunakan beberapa barang terpercaya, layanan atau merek terpercaya yang diyakini memiliki dampak positif terhadap lingkungan (Chen dan Chang, 2012). Green trust menurut Chen (2010) merupakan kehendak untuk bergantung pada 
sebuah produk, jasa atau mere katas dasar keyakinan atau harapan yang dihasilkan dari kredibilitas, perbuatan baik, dan kecakapan tentang kinerja lingkungannya.

\section{Green Purchase Itention}

Pada tahap tertentu dalam proses membeli, konsumen berhenti untuk mencari dan mengevaluasi informasi untuk membangkitkan tentang alternative merek-merek dan pada akhirnya melakukan keputusan pembelian (purchase decision). Pada posisi evaluasi, konsumen biasa mengembangkan niat untuk membeli (purchase intention) atau kecenderungan untuk membeli merek tertentu (Belch and Belch, 2009). Sehingga niat membeli produk hijau adalah apabila seorang konsumen mempunyai kecenderungan untuk mengambil tindakan membeli atau menggunakan suatu produk atau jasa yang telah diperkirakan atau dibayangkan bahwa produk tersebut ramah terhadap lingkungan.

\section{Kerangka Konsep Penelitian}

Penelitian tentang green marketing belum banyak dilakukan. Namun beberapa penelitian menemukan bahwa green marketing erat kaitannya dengan green perceived value, green brand image, dan green trust, serta green purchase intention. Green marketing tidak sekedar menawarkan sebuah produk yang ramah lingkungan, akan tetapi diterapkan sejak proses produksi, proses distribusi, kegiatan pemasaran, sampai kegiatan diluar aktivitas pemasaran harus berbasis pada kelestarian lingkungan dan ini merupakan suatu peluang potensial dan strategis, serta mendatangkan keuntungan ganda (multiplier effect) bagi pelaku bisnis maupun konsumen penggunanya (Manongko, 2011).

Masyarakat akan lebih memilih untuk membeli green product dengan informasi yang terpercaya dan memadai dan sebaliknya perusahaan harus memberikan informasi yang dapat dipercaya untuk konsumen guna mengurangi resiko yang akan dirasakan oleh pelanggan mereka (Peattie, 1992). Persepsi konsumen terhadap suatu produk dapat dibentuk melalui strategi tertentu. Green perceived value merupakan salah satu hal penting bagi green consumer (Kotler dan Keller, 2011).

Green perceived value tidak hanya menjadi penentu utama dalam mempertahankan konsumen jangka panjang, tetapi juga akan memainkan peran kunci dalam mempengaruhi minat membeli konsumen (Zhuang, 1997). Citra merek positif konsumen pada suatu produk dapat meningkatkan keinginan konsumen untuk membeli suatu produk. Ko et al. (2013) menunjukan bahwa hasil dari green marketing secara signifikan terkait 
dengan penciptaan sebuah green brand image yang positif untuk sebuah green product, dan hasilnya menunjukkan adanya green purchase intention untuk mempergunakan produk tersebut yang dipengaruhi oleh keunggulan produk dan pandangan tanggung jawab perusahaan.

Green brand image yang positif merupakan langkah awal suatu perusahaan untuk menarik lebih banyak pelanggan yang setia terhadap produk tersebut melalui sebuah strategi yang tepat (Juwaheer, 2012). Green brand image dan green perceived value mempengaruhi kepercayaan konsumen. Kepercayaan merupakan penentu utama perilaku konsumen dalam jangka panjang (Lee, et al. 2011). Kepercayaan merupakan factor penting dalam terbentuknya suatu hubungan (Chen, 2010). Jika pembeli memiliki kepercayaan terhadap penjual, mereka akan memiliki tingkat minat beli yang lebih tinggi (Asgharian, 2012).

Kepercayaan menjadi factor yang penting dalam proses pengambilan keputusan pembelian karena di dalam kepercayaan terdapat tingkat keyakinan diri terhadap pihak lain yang akan bertindak sesuai dengan yang diharapkan. Terutama pada green product, konsumen akan berniat untuk membeli produk tertentu berdasarkan kebutuhan lingkungan (Chen dan Chang, 2012). Green trust adalah kesediaan menggunakan beberapa barang terpercaya, layanan, atau merek terpercaya yang diyakini memiliki dampak positif terhadap lingkungan (Chen dan Chang, 2012).

Berdasarkan hasil penelitian sebelumnya, maka hubungan antara variable green perceived value, gree brand image, green trust, dan green purchase intention dapat dibuat pada kerangka konseptual sebagai berikut :

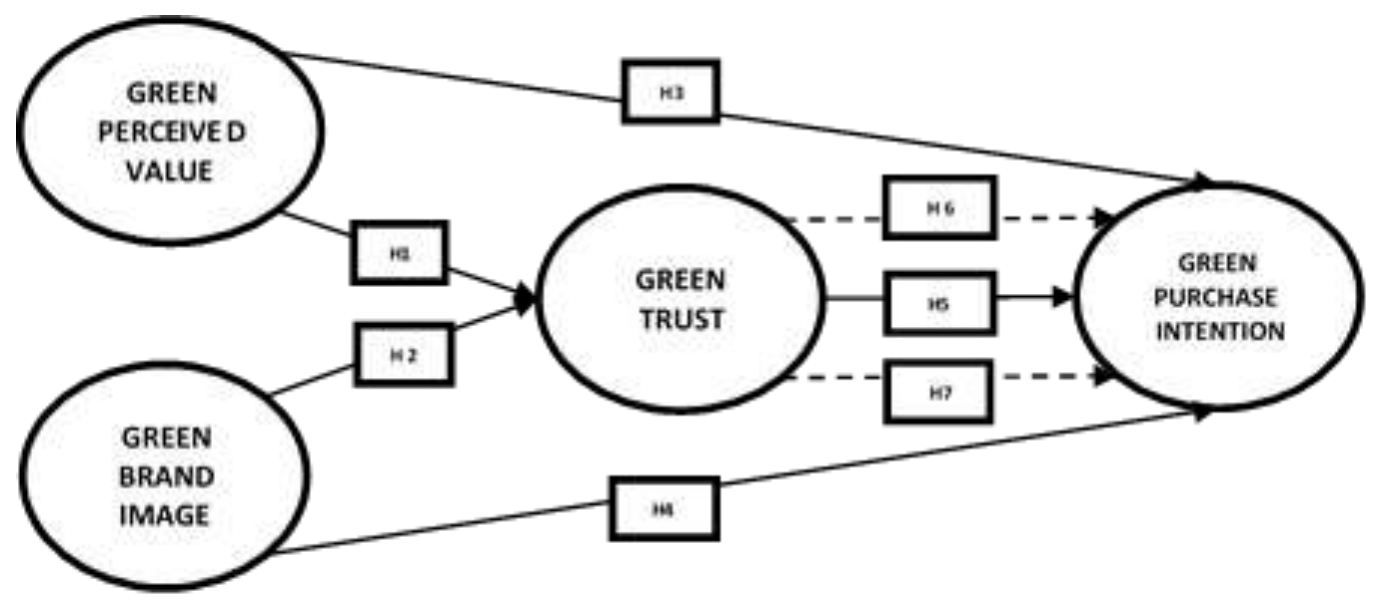

Gambar 1

Model Hipotesis

Sumber : Modifikasi Peneliti, 2018

6 | IQTISHODUNA Vol. 15 No. 1 Tahun 2019

http://ejournal.uin-malang.ac.id/index.php/ekonomi 


\section{Hipotesis Penelitian}

H1 : Green perceived value berpengaruh positif terhadap green trust

H2 : Green brand image berpegaruh positif terhadap green trust

H3 : Green perceived value berpengaruh positif terhadap green purchase intention

H4 : Green brand image berpengaruh positif terhadap green purchase intention

H5 : Green trust berpengaruh terhadap green purchase intention

H6 : Green trust sebagai mediasi pengaruh antara green perceived value terhadap green purchase intention

H7 : Green trust sebagai mediasi pengaruh green brand image terhadap green purchase intention

\section{Metodologi Penelitian}

Metode penelitian yang digunakan dalam penelitian ini adalah metode kuantitatif deskriptif yang bertujuan untuk mengkualifikasi data, yang diterapkan dalam analisis tertentu (Maholtra, 2004). Seluruh jumlah sample pada penelitian ini adalah 141 responden konsumen The Bodyshop Malang. Penelitian ini menggunakan metode purposive sampling dengan karakteristik : (1) berusia minimal 18 tahun (2) responden merupakan masyarakat yang berdomisili di kota Malang. (3) merupakan konsumen baik pria maupun wanita pengguna produk The Bodyshop lebih dari satu kali. Sedangkan teknik analisis data yang dilakukan menggunakan PLS atau Partial Least Square.

\section{Hasil Penelitian}

\section{Deskripsi Karakteristik Responden}

Hasil analisis penelitian ini menunjukkan bahwa dari 141 responden yang telah berpartisipasi dalam penelitian ini mayoritas perempuan sebanyak 78,7\%, sebagian besar berada dalam rentang usia 23-27 tahun dengan presentase $42,5 \%$ dan telah menempuh pendidikan strata 1 (S1) dengan presentase 63,8\%. Sebanyak 57,4\% responden telah menikah. Responden dalam penelitian ini sebanyak $44 \%$ adalah ibu rumah tangga dan pelaku wirausaha dengan pendapatan per bulan antara 3 juta sampai dengan 6 juta rupiah dan sudah mengenal produk The Bodyshop selama 3 sampai dengan 6 tahun.

Hasil penelitian menunjukkan bahwa nilai rata-rata distribusi frekuensi persepsi responden tentang indikator dari setiap variabel yang digunakan menunjukkan hasil yang baik. Rata-rata persepsi responden responden terhadap green percieved value sebesar $(3,95)$ terhadap green brand image 
Dewi Rakhmawati, Astrid Puspaningrum, Djumilah Hadiwidjojo

sebesar $(4,01)$ terhadap green trust sebesar $(3,93)$ terhadap green percieved value sebesar $(3,95)$ dan terhadap green purchase intention sebesar $(3,78)$.

\section{The Analysis Result of Partial Least Square}

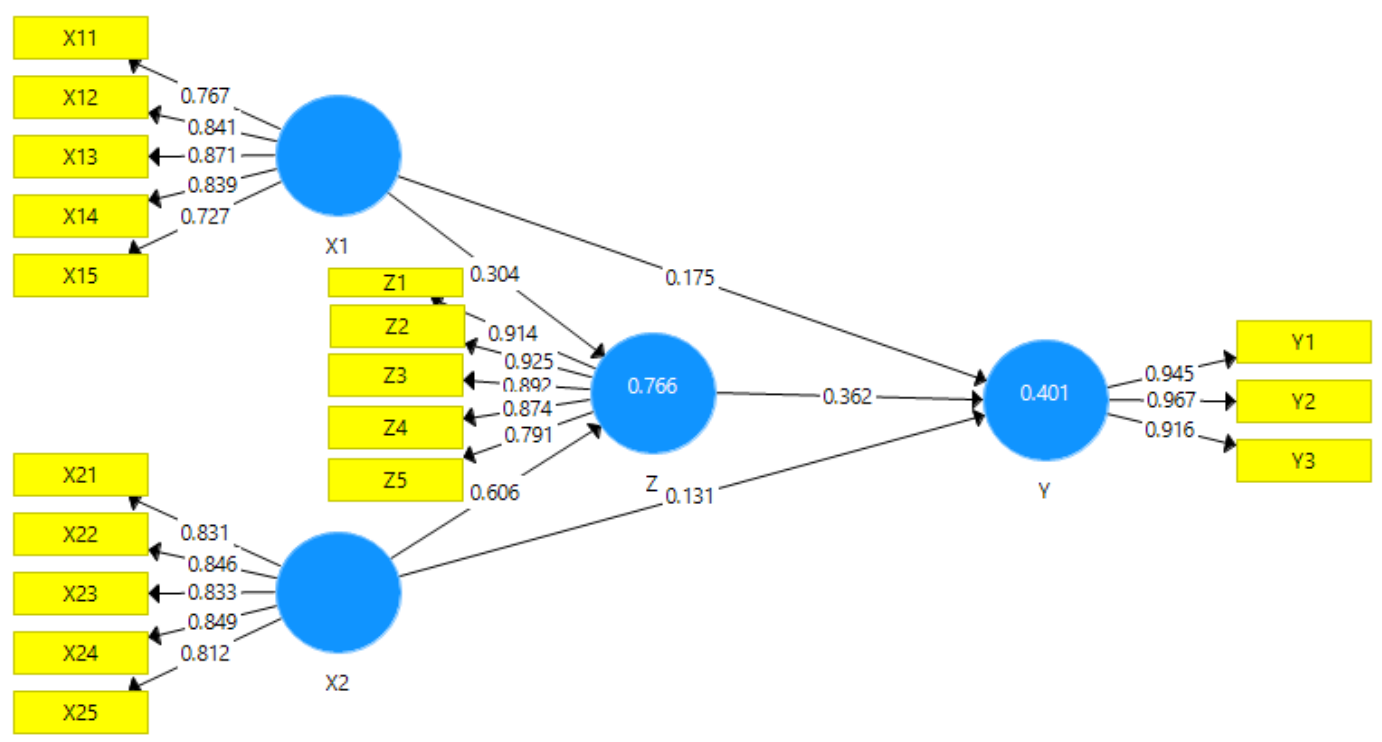

\section{Gambar 2. Hasil Analisis PLS}

Berdasarkan hasil analisis Convergent Validity dapat diketahui bahwa seluruh indikator pada penelitian ini menghasilkan loading factor yang lebih besar dari 0.7. dengan demikian seluruh indikator dinyatakan valid dalam mengukur masing-masing variabel.

Tabel 1. Nilai cross loading

\begin{tabular}{ccccr}
\hline & \multicolumn{4}{c}{ Variabel } \\
\cline { 2 - 5 } Indikator & $\begin{array}{c}\text { Green } \\
\text { Perceived } \\
\text { Value }\end{array}$ & $\begin{array}{c}\text { Green } \\
\text { Brand } \\
\text { Image }\end{array}$ & $\begin{array}{c}\text { Green } \\
\text { Trust }\end{array}$ & $\begin{array}{c}\text { Green } \\
\text { Purchase } \\
\text { Intention }\end{array}$ \\
\hline X1.1 & $\mathbf{0 , 7 6 7}$ & 0,584 & 0,521 & 0,428 \\
\hline X1.2 & $\mathbf{0 , 8 4 1}$ & 0,669 & 0,691 & 0,502 \\
\hline X1.3 & $\mathbf{0 , 8 7 1}$ & 0,709 & 0,680 & 0,471 \\
\hline X1.4 & $\mathbf{0 , 8 3 9}$ & 0,755 & 0,747 & 0,537 \\
\hline X1.5 & $\mathbf{0 , 7 2 7}$ & 0,636 & 0,606 & 0,381 \\
\hline X2.1 & 0,719 & $\mathbf{0 , 8 3 1}$ & 0,683 & 0,442 \\
\hline X2.2 & 0,731 & $\mathbf{0 , 8 4 6}$ & 0,713 & 0,547 \\
\hline X2.3 & 0,660 & $\mathbf{0 , 8 3 3}$ & 0,748 & 0,409 \\
\hline
\end{tabular}

8 | IQTISHODUNA Vol. 15 No. 1 Tahun 2019

http://ejournal.uin-malang.ac.id/index.php/ekonomi 
Hubungan Green Percieved Value, Green Brand Image...

\begin{tabular}{ccccc}
\hline X2.4 & 0,687 & $\mathbf{0 , 8 4 9}$ & 0,662 & 0,466 \\
\hline X2.5 & 0,669 & $\mathbf{0 , 8 1 2}$ & 0,764 & 0,570 \\
\hline Z1 & 0,703 & 0,774 & $\mathbf{0 , 9 1 4}$ & 0,531 \\
\hline Z2 & 0,788 & 0,817 & $\mathbf{0 , 9 2 5}$ & 0,589 \\
\hline Z3 & 0,684 & 0,797 & $\mathbf{0 , 8 9 2}$ & 0,532 \\
\hline Z4 & 0,719 & 0,733 & $\mathbf{0 , 8 7 4}$ & 0,613 \\
\hline Z5 & 0,656 & 0,648 & $\mathbf{0 , 7 9 1}$ & 0,434 \\
\hline Y1 & 0,550 & 0,536 & 0,531 & $\mathbf{0 , 9 4 5}$ \\
\hline Y2 & 0,595 & 0,596 & 0,665 & $\mathbf{0 , 9 6 7}$ \\
\hline Y3 & 0,478 & 0,525 & 0,535 & $\mathbf{0 , 9 1 6}$ \\
\hline
\end{tabular}

Sumber : Data primer diolah, 2018

Berdasarkan Tabel 1 diketahui bahwa setiap indikator pada variabel penelitian memiliki nilai cross loading terbesar pada variabel formatifnya dibandingkan nilai cross loading pada variabel lain. Karenanya dapat dinyatakan bahwa masing-masing indikator yang digunakan untuk penelitian ini memiliki discriminant validity yang baik dalam menyusun variabel masingmasing.

Hasil nilai Cronbach's Alpha pada green perceived value sebesar 0.869 , green brand image sebesar 0.891, green trust sebesar 0.938 dan green purchase intention sebesar 0.927 dimana menunjukkan bahwa setiap variabel penelitian telah memenuhi syarat nilai cronbach alpha, sehingga dapat disimpulkan bahwa keseluruhan variabel memiliki tingkat reliabilitas yang tinggi.

Berdasarkan skema inner model yang telah ditampilkan dapat dijelaskan bahwa nilai path coefficient terbesar ditunjukkan dengan pengaruh green brand image terhadap green trust sebesar 5,286. Kemudian pengaruh terbesar berikutnya adalah green perceived value terhadap green trust sebesar 2,694. Pengaruh terbesar selanjutnya adalah green trust terhadap green purchase intention sebesar 2,083. Sedangkan pengaruh terkecil berturut-turut adalah green perceived value terhadap green purchase intention sebesar 1,049; kemudian green brand image terhadap green purchase intention sebesar 0,571.

Hasil uji R2 untuk variabel green purchase intention adalah 0,401; dan nilai variabel green trust adalah sebesar 0,766. Perolehan nilai tersebut menjelaskan bahwa variabel green perceived value dan green brand image memberikan pengaruh sebesar 40,1\% terhadap green purchase intention, dengan 59,9\% dipengaruhi oleh variabel lain di luar penelitian. Kemudian

IQTISHODUNA Vol. 15 No. 1 Tahun 2019| 9 http://ejournal.uin-malang.ac.id/index.php/ekonomi 
Dewi Rakhmawati, Astrid Puspaningrum, Djumilah Hadiwidjojo

variabel green perceived value dan green brand image memberikan pengaruh terhadap green trust sebesar 76,6\%, dengan $23,4 \%$ dipengaruhi oleh variabel lainnya.

\section{Pengujian Hipotesis}

Pengujian hipotesis pada penelitian dilakukan dengan melihat hasil original sample estimate dan t-Statistics, dimana hipotesis dapat dinyatakan diterima bila nilai original sample estimate adalah positif dengan nilai tStatisctic sebesar $>1,96$ atau lebih besar dari t-table. Berikut adalah hasil uji hipotesis yang diperoleh melalui inner model dalam penelitian ini :

Tabel 2. t-Statistics dan P Values

\begin{tabular}{|c|c|c|c|}
\hline Hipotesis & $\begin{array}{l}\text { T- } \\
\text { Statistics }\end{array}$ & $\begin{array}{l}\text { Original } \\
\text { Sample } \\
\text { Estimate }\end{array}$ & Keterangan \\
\hline $\begin{array}{l}\text { Green perceived value } \\
\text { berpengaruh terhadap green trust } \\
\text { (H1) }\end{array}$ & 2,694 & 0,304 & $\begin{array}{l}\text { Positif } \\
\text { signifikan }\end{array}$ \\
\hline $\begin{array}{l}\text { Green brand image berpengaruh } \\
\text { terhadap green trust }(\mathbf{H} 2)\end{array}$ & 5,286 & 0,606 & $\begin{array}{l}\text { Positif } \\
\text { signifikan }\end{array}$ \\
\hline $\begin{array}{ll}\text { Green perceived } & \text { value } \\
\text { berpengaruh terhadap } & \text { green } \\
\text { purchase intention (H3) } & \end{array}$ & 1,049 & 0,175 & $\begin{array}{l}\text { Positif, tidak } \\
\text { signifikan }\end{array}$ \\
\hline $\begin{array}{l}\text { Green brand image berpengaruh } \\
\text { terhadap green purchase intention } \\
\text { (H4) }\end{array}$ & 0,571 & 0,120 & $\begin{array}{l}\text { Positif, tidak } \\
\text { signifikan }\end{array}$ \\
\hline $\begin{array}{l}\text { Green trust berpengaruh terhadap } \\
\text { green purchase intention (H5) }\end{array}$ & 2,083 & 0,364 & $\begin{array}{l}\text { Positif } \\
\text { signifikan }\end{array}$ \\
\hline $\begin{array}{l}\text { Green trust sebagai mediasi antara } \\
\text { green perceived value terhadap } \\
\text { green purchase intention }(\mathbf{H 6})\end{array}$ & 0,702 & $-0,130$ & $\begin{array}{l}\text { Positif, tidak } \\
\text { signifikan }\end{array}$ \\
\hline $\begin{array}{l}\text { Green trust sebagai mediasi antara } \\
\text { green brand image terhadap green } \\
\text { purchase intention (H7) }\end{array}$ & 0,722 & 0,130 & $\begin{array}{l}\text { Positif, tidak } \\
\text { signifikan }\end{array}$ \\
\hline
\end{tabular}

Sumber : Data primer diolah, 2018

\section{Pembahasan}

Hasil penelitian ini menunjukkan responden merasakan bahwa kepedulian The Bodyshop terhadap lingkungan yang diekspektasikan konsumen sesuai dengan harapan sehingga dapat meningkatkan kepercayaan konsumen. Hasil ini sesuai dengan penelitian yang dilakukan oleh Chen \& Chang (2012), yang juga menunjukkan bahwa green perceived value memiliki 
pengaruh positif terhadap green trust. Semakin tinggi nilai yang dipersepsikan oleh konsumen, maka kepercayaan pada suatu produk turut meningkat. Hasil rata-rata jawaban responden menunjukkan bahwa konsumen memiliki persepsi bahwa The Bodyshop adalah sebuah produk yang ramah lingkungan serta mendukung program-program ramah lingkungan yang digagas oleh perusahaan.

Hasil penelitian ini menunjukkan bahwa green brand image pada akhirnya juga dapat mempengaruhi sebuah kepercayaan atas suatu green product, sebagaimana penelitian Chen (2010) yang menemukan adanya hubungan positif green brand image terhadap green trust. Jawaban responden menunjukkan bahwa The Bodyshop memiliki komitmen menjaga lingkungan dan hal ini turut membangun kepercayaan konsumen. hal yang ditunjukkan oleh The Bodyshop adalah upaya daur ulang kemasan bekas. Hal in mendukung kepercayaan konsumen terhadap image hijau yang diciptakan oleh The Bodyshop sebagi produk yang berkontribusi bagi lingkungan.

Pada hipotesis ketiga, hasil yang diperoleh berbeda dengan hasil penelitian Doszhanov \& Ahmad (2015), dan Rahardjo (2015) yang menemukan adanya hubungan positif dan signifikan antara green perceived value terhadap green purchase intention. Pada penelitian yang telah dilakukan sebelumnya, persepsi konsumen menjadi salah satu faktor fundamental yang mendasari niat pembelian suatu produk. Adapun penjelasan terkait pengaruh tidak signifikan antara green perceived image terhadap green purchase intention produk The Body Shop adalah kurangnya informasi yang mampu membentuk persepsi konsumen.

Hasil penelitian menunjukkan bahwa citra hijau The Bodyshop yang diciptakan tidak cukup mempengaruhi konsumen untuk membeli. Hasil ini berbeda dengan temuan pada penelitian terdahulu yang dilakukan Bian \& Moutinho (2011) di mana brand image menjadi faktor yang paling dominan dalam mempengaruhi purchase intention, serta Lien, et al. (2015) yang menyatakan bahwa brand image menjadi satu dari tiga faktor krusial penentu purchase intention. Akan tetapi hasil penelitian ini didukung oleh penelitian Alshura \& Zabadi (2016), yang tidak menemukan pengaruh signifikan brand image terhadap green product. Tingkat pengetahuan konsumen terhadap suatu produk hijau menjadi faktor yang menentukan niat pembelian produk dalam penelitian tersebut. Aktivitas green marketing dijabarkan Ko et al. (2013) sebagai upaya signifikan dalam penciptaan green brand image yang positif untuk sebuah green product, dan menghasilkan green purchase intention untuk menggunakan produk yang dipengaruhi oleh keunggulan produk dan pandangan tanggung jawab sosial perusahaan. 
Berdasarkan komentar responden pada kuesioner diketahui bahwa mayoritas konsumen telah mengenal reputasi The Body Shop sebagai produk yang ramah lingkungan, melalui beberapa program di bidang pelestarian alam dan proses produksi yang menentang animal testing. Namun niat pembelian produk secara signifikan lebih dipengaruhi oleh variabel lain yang tidak disebutkan dalam penelitian ini, seperti kualitas produk, bahan yang digunakan, dan kecocokan produk terhadap kulit konsumen.

Hasil penelitian menunjukkan bahwa green trust mempengaruhi keinginan konsumen untuk membeli. Hasil ini sesuai dengan penelitian Chen \& Chang (2012), Lien, et al. (2015), Doszhanov \& Ahmad (2015), Rahardjo (2105), dan Alshura \& Zabadi (2016) yang menunjukkan bahwa green trust mempengaruhi green purchase intention secara positif dan signifikan. Chen \& Chang (2012) menekankan adanya hubungan green trust terhadap green purchase intention terutama pada konsimen yang memiliki pertimbangan lingkungan pada saat akan melakukan pembelian produk hijau. Lebih jauh, konsumen tidak akan membeli green product yang tidak dipercayainya.

Hasil penelitian menunjukkan bahwa tidak terdapat pengaruh positif green trust sebagai mediasi variabel green perceived value terhadap green purchase intention dan terdapat pengaruh citra merek hijau terhadap niat beli konsumen The Bodyshop yang dimediasi oleh kepercayaan konsumen.

\section{Kesimpulan}

Berdasarkan hasil penelitian dan pembahasan, maka dapat diambil kesimpulan dalam penelitian ini bahwa keinginan membeli konsumen terhadap produk ramah lingkungan dipengaruhi secara langsung oleh kepercayaan konsumen. Konsumen mengetahui dan memahami dengan baik bahwa image kosmetik ramah lingkungan yang ada dalam benak mereka adalah merek The Bodyshop.

Hal ini dikarenakan The Bodyshop konsisten melakukan kegiatan baik produksi, promosi dan kegiatan kepedulian lingkungan lainnya dan menepati komitmennya terhadap lingkungan. Persepsi konsumen dan image ramah lingkungan yang diciptakan The Bodyshop yang dilakukan secara terus menerus dapat meningkatkan kepercayaan konsumen yang nantinya berpengaruh pada peningkatan jumlah pembelian.

Berdasarkan kesimpulan yang telah dijelaskan sebelumnya, saran yang dapat diberikan dari hasil penelitian adalah pemilihan model pemasaran yang tepat salah satunya sosialisasi mengenai program dan produk sebagai pengetahuan umum konsumen, beserta konsekuensi produk yang menunjukkan tanggung jawab mereka terhadap lingkungan terutama 
manfaatnya bagi konsumen. Pengenalan produk yang dilakukan tidak hanya sebatas penggunaan bahan alami dan tidak melakukan uji coba terhadap hewan, namun lebih kepada pengaruh yang akan dirasakan konsumen ketika menggunakan produk tersebut terhadap kecantikan mereka. Pengenalan program yang menarik konsumen umumnya suatu bentuk aktivitas yang sangat dekat dengan keseharian konsumen sehingga konsumen akan lebih mudah memahami dan menyimpannya ke dalam pikiran. The Bodyshop disarankan meningkatkan variasi produk terutama yang menggunakan bahan alami yang berasal asli dari Indonesia sehingga konsumen local Indonesia lebih tertarik dan percaya.

\section{Daftar Pustaka}

Alshura, M. S., Zabadi, A. M. 2016. Impact Of Green Brand Trust, Green Brand Awareness, Green Brand Image, And Green Perceived Value On Consumer's Intension To Use Green Products: An Empirical Study of Jordanian Consumers. International Journal of Advanced Research. 4(2). 1423-1433.

Ardianti, T. Nadya. 2008. Analisis Perilaku Konsumen Kota Bogor terhadap Produk kosmetika Hijau. Tesis Program Pascasarjana Manajemen dan Bisnis IPB.

Asgharian, R. 2012. Green Product Quality, Green Customer Satisfaction, and Green Customer Loyalty. International Journal of Research in Management \& Technology. Vol. 2 (5), pp. 2249-9563.

Ashton, A.S., Scott, N., Solnet, D. \& Breakey, N. 2010. Hotel Restaurant Dining: The Relationship between Perceived Value and Intention to Purchase. Tourism and Hospitality Research. Vol. 10 No. 3, pp. 206-18.

Belch, G. E. \& Belch, M. A. 2009. Advertising and Promotion: An Integrated Marketing Communications Perspective. $8^{\text {th }}$ Edition. New York: McGrawHill.

Bian, X., Moutinho, L. 2011. The role of brand image, product involvement, and knowledge in explaining consumer purchase behaviour of counterfeits: Direct and indirect effects. European Journal of Marketing. 45. (1/2). 191-216.

Chen, Yu-Shan. 2009. The Drivers of Green Brand Equity: Green Brand Image, Green Satisfaction, and Green Trust. Journal of Business Ethics. 93, p. 307-319.

Chen, Yu-Shan. 2010. The Organizational Identity: Source and Consequence. Management Decision. Vol. 49, No. 3, p. 384-404. 
Chen. Y.S. \& Chang. C.H. 2012. Enhance Green Purchase Intentions: The Roles of Green Perceived Value, Green Perceived Risk, and Green Trust. Management Decision. Vol.50, No. 3, p. 502-520.

Dahlstrom, Robert. 2011. Green Marketing Management. University of Kentucky. South-Western Cengage Learning.

Doszhanov, A. \& Ahmad, Z.A 2015. Customers' intention to use green products: The impact of green brand dimensions and green perceived value. SHS Web of Conferences, 18, 01008. doi:10.1051/shsconf 20151801008

Juwaheer T.D, S. Pudaruth \& M.M.E Noyaux 2012. Analysis the Impact of Green marketing strategies on consumer purchasing strategies on consumer purchasing patterns in maturitius. Word Journal of entrepreneurship. Management and Sustaineble Development. Vol. 8(1), pp. 36-59.

Ko, E., Hwang, Y. K. \& Kim, E. Y. 2013. Green Marketing' Functions in Building Corporate Image in the Retail Setting. Journal of Business Research. 66, (10), 1709-1715.

Kotler, P. \& Keller, K. L. 2011. Manajemen Pemasaran, Edisi 13 Jilid 1 dan 2, Jakarta: Erlangga.

Kotler, Philip dan Kevin Lane Keller, 2008. Manajemen Pemasaran, Jilid 1, Penerbit Erlangga. Jakarta.

Lien, C. H., Wen, M. J., Huang, L. C., \& Wu, K. l. 2015. Online Hotel Booking: The Effect of Brand Image, Price, Trust, and Value on Purchase Intention. Asia Pacific Management Review Vol. 20, p. 210-218.

Lee, J., Park, D. H. \& Han, I. 2011. The different effects of online consumer reviews on consumers' purchase intentions depending on trust in online shopping malls: an advertising perspective. Internet Research. Vol. 21 No. 2, pp. 187-206.

Malhotra, Naresh. K, 2004. Riset Pemasaran: Pendekatan Terapan. Edisi Bahasa Indonesia. Jakarta: PT. Indeks Kelompok Gramedia.

Manongko, Allen. A. Ch. 2011. Green Marketing dan Pengaruhnya terhadap Keputusan Pembelian melalui Minat Membeli Produk Organik. (Studi Pada Pelanggan Produk Organik di Kota Manado). Program Pascasarjana Fakultas Ekonomi Universitas Brawijaya.

Mourad, M. \& Ahmed, Y. S. E. 2012. Perception of Green Brand in An Emerging Innovative Market. European Journal of Innovation Management. 15(4). 514-537.

Patterson, P. and Spreng, R. 1997. Modeling the Relationship between Perceived Value, Satisfaction and Repurchase Intention in A Business-tobusiness, Service Context: An Empirical Examination. International Journal of Service Industry Management. Vol. 8 No. 5, pp. 414-34.

Peattie, K. 1992. Green Marketing. London: Pitman Publishing. 
Rahardjo., F. A. 2015. The Roles Of Green Perceived Value, Green Perceived Risk Towards Green Purchase Intention Of Inverter Air Conditioner in Surabaya. iBuss Management, 3(2): pp: 252-260.

Shaputra, Rizky K. 2013. Penerapan Green Marketing pada Bisnis Produk Kosmetik. Jurnal JIBEKA, Vol. 7, no. 3, Agustus, p. 47-53.

Sweeney, J. C., Soutar, G. N. \& Johnson, L. W. 1999. The Role of Perceived Risk in the Quality-Value Relationship: A Study in A Retail Environment", Journal of Retailing, Vol. 75 No. 1, pp. 77-105.

Wibowo, Buddi. 2001. Green Consumerism dan Green Marketing: Perkembangan Perilaku Konsumen dan Pendekatan Pemasaran Usahawan, No. 6, Juni, p.12-15.

Zeithaml, V.A. 1988. Consumer Perceptions of Price, Quality, and Value: A Means-end Model and Synthesis of Evidence", Journal of Marketing, Vol. 52 No. 3, pp. 2-22.

Zhuang, W. 1997. The impact of perceived value on behavior intention: an empirical study. Journal of the Academy of Marketing Science. Vol. 4 (3), p.34-54. 
Dewi Rakhmawati, Astrid Puspaningrum, Djumilah Hadiwidjojo

16 | IQTISHODUNA Vol. 15 No. 1 Tahun 2019

http://ejournal.uin-malang.ac.id/index.php/ekonomi 